\title{
Losses Due to Red Rot Pathogen in Cane Juice Quality
}

\author{
Md. Minnatullah ${ }^{1 *}$ and D.N. Kamat ${ }^{2}$ \\ ${ }^{1}$ Department of Plant Pathology, SRI, DRPCAU, Pusa, Bihar-848125, India \\ ${ }^{2}$ Department of Plant Breeding, SRI, DRPCAU, Pusa, Bihar-848125, India \\ *Corresponding author
}

\begin{tabular}{|l|}
\hline Key w or d s \\
Sugarcane, Losses, \\
Red rot, Juice
\end{tabular}

\section{A B S T R A C T}

Red rot disease of sugarcane is caused by Colletotrichum falcatum Went, a disease of major importance in the most of sugarcane growing state of India. Red rot caused a wide range of reduction in juice quality and also it is responsible for degeneration of varieties in sugarcane. The present investigation was under taken at SRI, Pusa, to assess the deterioration in cane juice quality induced by red rot pathogen. The observation clearly revealed that there was an appreciable reduction in the juice quality i.e. Pol, Brix and Purity. However, the extent of losses varied according to the pathogenic behavior of the isolates and the degree of resistance of cane varieties. Maximum reduction was observed in susceptible genotypes i.e. - CoSe 95422, CoS 8436 and BO 128. The reduction ranging from 16.60 to 20.80 per cent in Brix, 31.60 to 38.26 per cent in Pol and 18.00 to $22.10 \%$ per cent in purity. Whereas, minimum reduction was observed in resistant and moderately resistant genotypes which ranged from 2.00 to $8.00 \%$ in brix, 6.10 to 19.38 per cent in pol and 4.20 to 12.40 per cent in purity. Therefore, it can be concluded that red rot pathogen impaired the cane juice quality. The resistant variety is the best solution to overcome red rot disease as chemical control measures against red rot is not too much feasible, when it occurred. Thus, during development of sugarcane varieties sincere efforts should be made by Breeders and Pathologists for effective screening of resistant varieties against red rot pathogen.

\section{Introduction}

In India sugarcane is cultivated in an area of 5.3 million ha with total production of 346 million tons and it has productivity of 64.7 t/ha. In Bihar, it is cultivated in 0.3 million ha with total production of 149 million tons with an average productivity of 50 t/ha (ISMA, 2016). Cane yield is markedly influence by several factors of which diseases are known to inflict considerable losses in production as well as sugar recovery. Among these factors red rot disease caused huge financial losses to the farmers by deteriorating the juice quality and the overall production of sugarcane (Natrajan and Muthuswamy, 1981). It is also responsible for degeneration of varieties in sugarcane (Viswanathan, 2010). Juice quality parameters are very important index in defining the sugar recovery. Therefore, the present study was carried out at Pusa Farm, Sugarcane Research Institute, Dr. RPCAU, Pusa (Bihar) to assess the extent of reduction in juice induced by red rot pathogen. 


\section{Materials and Methods}

To elucidate the influence of red rot infection on juice quality, a field trial was conducted at Pusa Farm, Sugarcane Research Institute, Dr. Rajendra Prasad Central Agricultural University, Pusa (Bihar). Three budded sets of twenty entries were planted in three rows of $10 \mathrm{mts}$. long in the $1^{\text {st }}$ week of February. Recommended agronomical practices for sugarcane production were followed. Twenty five standing canes of each variety were artificially inoculated) by plug method with red rot fungus (Colletotrichum falcatum) in the middle of $4^{\text {th }}$ exposed internodes from the bottom in the first week of August. After injecting the inoculum the hole was replugged with removed cane tissues and sealed immediately with wax coated paper to avoid external contamination. Inoculated canes were split opened longitudinally after 60 days of inoculation and data were recorded using 0-9 scale (Srinivasan and Bhat, 1961) by considering the condition of cane tops (0-1), lesion width (0-3), nature of white spot (0-2) and nodal transgression of red rot lesions (13). Juice samples were obtained from inoculated (diseased) and uninoculated (healthy) canes to determine the juice quality. Brix was measured by brix hydrometer, pol (Sucrose) by polariscope, and purity was recorded as coefficient of purity according to method of Browne and Zerban (1941) and Spancer and Meade (1955). The reduction and purity coefficient calculated by

$\frac{H-D}{H} \times 100$ and $\frac{P o l q 6}{B r i x} \%$ X 100 , respectively.

Where, $\mathrm{H}=$ Healthy cane, $\mathrm{D}=$ Diseased cane, $\mathrm{R}=$ Reduction.

\section{Results and Discussion}

The extent of reduction in juice quality in respect of Brix, Pol and Purity were determined and the data depicted in Table 1.
Result showed that the maximum reduction was recorded in varieties BO $128, \operatorname{CoS} 8436$ and CoSe 95422 which were graded as highly susceptible and susceptible, respectively. The varieties CoSe 92423 and $\mathrm{CoX} 07137$ were graded as moderately susceptible. Among the varieties, six varieties (BO 141, BO 110, BO 154, BO 153, CoP 9301 and CoP 11437) and nine varieties (CoX 07141, CoP 11438, CoP 133, CoP 11436, CoP 09437, BO 155, CoP 11439, BO 91 and CoP 11440) were found resistant and moderately resistant against red rot pathogen, respectively. The maximum reduction was observed in susceptible varieties which ranged from 16.60 to 20.80 per cent in Brix, 31.60 to 38.26 per cent in Pol (sucrose) and 18.00 to 22.10 percent in purity. Whereas, minimum reduction was recorded in resistant and moderately resistant varieties which ranged in between 2.00 to 8.00 per cent in brix, 6.10 to 19.38 per cent in Pol and 4.2012.40 per cent in purity. While, intermediate deterioration in juice quality was observed in moderately susceptible sugarcane varieties (CoX 07137 and CoX 07141) which ranged in between 15.00 to 15.42 per cent in brix, 27.75 to 28.79 percent in Pol and 15.00 to 15.80 per cent in purity.

The decline in brix might be possibly due to utilization of some solid materials of cane juice by the isolates of red rot pathogen as a substrate. The depletion in brix was also observed by Rao et al., (1984). Decline in Pol might be due to inversion of sucrose into reducing sugar. Decrease in purity was due to low value to sucrose and brix of cane juice. Impaired sucrose synthesis as well as inversion of sucrose associated with an increase in moisture content might be the major factors for deterioration of cane purity. Singh and Waraitch (1977) also found a substantial reduction in purity due to red rot infection. Kumar (1992) and Minnatullah et al., (2012) also found substantial reduction in these parameters due to red rot infection. 
Table.1 Extent of reduction in juice quality induced by red rot pathogen

\begin{tabular}{|c|c|c|c|c|c|c|c|c|c|c|c|c|}
\hline \multirow{2}{*}{$\begin{array}{l}\text { Sl. } \\
\text { No. }\end{array}$} & \multirow[t]{2}{*}{ Varieties } & \multirow{2}{*}{$\begin{array}{l}\text { Disease } \\
\text { score }\end{array}$} & \multirow[t]{2}{*}{ Rating } & \multicolumn{3}{|c|}{ Brix \% } & \multicolumn{3}{|c|}{ Pol \% } & \multicolumn{3}{|c|}{ Purity \% } \\
\hline & & & & $\mathbf{H}$ & D & $\mathbf{R}$ & H & D & $\mathbf{R}$ & $\mathbf{H}$ & D & $\mathbf{R}$ \\
\hline 1 & BO 128 & 8.2 & HS & 14.00 & 11.09 & 20.80 & 9.80 & 6.05 & 38.26 & 70.00 & 54.53 & 22.10 \\
\hline 2 & CoS 8436 & 7.8 & $\mathrm{~S}$ & 15.20 & 12.10 & 19.70 & 11.00 & 6.99 & 36.45 & 72.37 & 57.75 & 20.20 \\
\hline 3 & CoSe 95422 & 6.5 & $\mathrm{~S}$ & 15.80 & 12.82 & 18.86 & 11.80 & 7.75 & 34.32 & 74.68 & 60.49 & 19.00 \\
\hline 4 & CoSe 92423 & 6.2 & MS & 16.00 & 13.34 & 16.60 & 12.50 & 8.55 & 31.60 & 78.12 & 64.06 & 18.00 \\
\hline 5 & CoX 07137 & 5.2 & MS & 16.60 & 14.04 & 15.42 & 13.20 & 9.40 & 28.79 & 79.52 & 66.96 & 15.80 \\
\hline 6 & CoX 07141 & 4.6 & MR & 16.80 & 14.28 & 15.00 & 13.80 & 9.97 & 27.75 & 82.14 & 69.82 & 15.00 \\
\hline 7 & CoP 11438 & 3.4 & MR & 17.00 & 15.64 & 8.00 & 14.60 & 11.77 & 19.38 & 85.88 & 75.23 & 12.40 \\
\hline 8 & CoP 133 & 3.3 & MR & 17.30 & 15.98 & 7.63 & 14.80 & 12.03 & 18.72 & 85.55 & 75.28 & 12.00 \\
\hline 9 & CoP 11436 & 3.1 & MR & 17.40 & 16.11 & 7.41 & 15.20 & 12.45 & 18.09 & 87.36 & 77.31 & 11.50 \\
\hline 10 & CoP 09437 & 3.0 & MR & 17.40 & 16.15 & 7.20 & 15.20 & 12.50 & 17.76 & 87.36 & 77.40 & 11.40 \\
\hline 11 & BO 155 & 2.8 & MR & 17.70 & 16.46 & 7.00 & 15.80 & 13.44 & 14.94 & 89.93 & 81.66 & 9.20 \\
\hline 12 & CoP 11439 & 2.6 & MR & 18.80 & 16.59 & 6.80 & 16.10 & 13.75 & 14.60 & 90.45 & 82.88 & 8.36 \\
\hline 13 & BO 91 & 2.2 & MR & 18.20 & 17.09 & 6.37 & 16.40 & 14.09 & 14.08 & 90.11 & 82.72 & 8.20 \\
\hline 14 & CoP 11440 & 2.1 & MR & 18.20 & 17.16 & 5.71 & 16.40 & 14.20 & 13.41 & 90.11 & 82.76 & 8.16 \\
\hline 15 & BO 141 & 2.0 & $\mathrm{R}$ & 18.60 & 17.62 & 5.27 & 16.50 & 14.52 & 12.00 & 88.71 & 82.41 & 7.10 \\
\hline 16 & BO 110 & 1.8 & $\mathrm{R}$ & 18.80 & 18.01 & 4.20 & 16.60 & 14.69 & 11.51 & 88.30 & 81.59 & 7.60 \\
\hline 17 & BO 154 & 1.6 & $\mathrm{R}$ & 19.40 & 18.63 & 3.97 & 16.80 & 15.10 & 10.12 & 86.60 & 81.06 & 6.40 \\
\hline 18 & BO 153 & 1.5 & $\mathrm{R}$ & 19.40 & 18.66 & 3.81 & 17.40 & 15.73 & 9.60 & 89.69 & 84.31 & 6.00 \\
\hline 19 & CoP 9301 & 1.2 & $\mathrm{R}$ & 19.60 & 18.99 & 3.57 & 17.60 & 16.15 & 8.24 & 89.79 & 85.03 & 5.30 \\
\hline 20 & CoP 11437 & 1.0 & $\mathrm{R}$ & 20.00 & 19.60 & 2.00 & 18.20 & 17.09 & 6.10 & 91.00 & 87.18 & 4.20 \\
\hline
\end{tabular}

The varieties were graded as

\begin{tabular}{|l|l|}
\hline Score & Reaction \\
\hline $\mathbf{0 . 0}-2.0$ & Resistant (R) \\
\hline $2.1-4.0$ & Moderately resistant (MR) \\
\hline $4.1-6.0$ & Moderately susceptible (MS) \\
\hline $6.1-8.0$ & Susceptible (S) \\
\hline Above 8.0 & Highly susceptible (HS) \\
\hline
\end{tabular}


Thus, it may be inferred that red rot disease caused considerable losses in juice quality and in part of the farmers as well as sugar mills owners.

The extent of losses in Juice quality was directly correlated with the levels of red rot infection and the degree of resistant of cane varieties.

Therefore, the resistant variety is the best solution to overcome red rot disease as chemical control measures is not too much feasible, against red rot when it occurred.

It is essential that the sincere efforts should be made for development of sugarcane varieties by Breeders and Pathologists for effective screening of resistant varieties against red rot disease.

\section{Recommendations}

Red rot is a dreadful disease in sugarcane which is difficult to manage through chemicals. Development of resistant varieties against red rot pathogen is the only option.

Therefore, screening of sugarcane varieties for red rot pathogen through suitable method may be adopted sincerely to develop red rot resistant varieties of sugarcane to maintain the juice quality in the best interest of cane growers as well as sugar factories.

\section{References}

Browne, C. A. and Zerban, F.W. 1941. Sugar Analysis New York. PP. 241-401.

ISMA, 2016. States wise sugarcane acreage, production and yield of sugarcane in India, Indian Sugar: LXV (11): 43-45.

Kumar, S. 1992. Juice quality and mineral nutrients status in red rot infected cane juice. Bhartiya Sugar. 17 (4):23-30.

Minnatullah, Md. Patel, A. K. Dohare, S. and Akhtar Reyaz 2012. Reduction in cane juice quality due to red rot infection. Indian Sugar May: 27-30.6

Natrajan, S. and S. Muthuswamy 1981. Screening of sugarcane clones for resistance to red rot. Sugarcane Pathol. News, 26:33-34.

Rao, P.R.K., Reddy, M.S., Rao, P.N., Narendranath, V.V. and Reddy, G. 1984. Indian Sugar 11:615:620.

Singh, O. and Waraitich, K. S. 1977. Sugarcane Pathol. Newletter, 19:7-9.

Spancer, G.L. and Meade, C. P. 1955. Cane Sugar Hand Book pp. 359.

Srinivasan, K.V. and Bhat, N.R. 1961. Red rot of Sugarcane: criteria for grading resistance Journal of Indian Bot. Society, 40: 566-77.

Viswanathan, R. 2010. Plant diseases: Red rot of sugarcane Anmol Publication Pvt. Ltd. New Delhi, 301 p.

\section{How to cite this article:}

Md. Minnatullah and Kamat, D.N. 2018. Losses Due to Red Rot Pathogen in Cane Juice Quality. Int.J.Curr.Microbiol.App.Sci. 7(02): 13-16.

doi: https://doi.org/10.20546/ijcmas.2018.702.003 